MIROSŁAW MEJZNER, RZYM-WARSZAWA

\title{
NAGRODA RATZINGERA 2015
}

W sobotnie przedpołudnie 21 listopada 2015 r. odbyła się w Watykanie podniosła uroczystość wręczenia Nagrody Ratzingera, którą w piątej edycji otrzymali o. prof. Mario de França Miranda SJ z Brazylii i prof. Nabil El-Khoury z Libanu.

Nagroda ta, określana mianem „teologicznego Nobla”, jest przyznawana najwybitniejszym teologom przez założoną w 2010 r. watykańską Fundację Józefa Ratzingera - Papieża Benedykta XVI. Dotychczas zostali nią uhonorowani następujący naukowcy: w 2011 r. - o. prof. Maximilian Heim, dogmatyk, przeor cystersów w Heiligenkreutz (Austria), prof. Manlio Simonetti, patrolog (Włochy) oraz prof. Olegario González de Cardedal, dogmatyk (Hiszpania); w 2012 r. - prof. Rémi Brague, filozof i historyk myśli (Francja) oraz prof. Brian E. Daley, SJ, teolog (USA); w 2013 r. prof. Richard Burridge, anglikański pastor i egzegeta (Wielka Brytania) oraz dr Christian Schaller, teolog świecki i edytor dzieł zebranych J. Ratzingera (Niemcy); w 2014 r. - prof. Anne-Marie Pelletier, biblista (Francja) oraz ks. prof. Waldemar Chrostowski, biblista i wybitny popularyzator Biblii. Lista laureatów wskazuje na prawdziwie międzynarodowy charakter Nagrody. Z jeszcze większą jasnością ukazał się on w piątej edycji 2015 r., dzięki uznaniu zasług teologów pozaeuropejskich. W uzasadnieniu wyboru podkreślono, że jeden z nagrodzonych pochodzi z kontynentu, który wydał pierwszego papieża spoza Europy, natomiast drugi jest przedstawicielem Kościołów wschodnich. Nagroda staje się więc jeszcze bardziej czytelnym znakiem powszechności Kościoła otwartego na dialog ze wszystkimi kulturami.

Mario de Franç a Miranda urodził się 24 lipca 1936 r. w Rio de Janeiro (Brazylia). W 1955 r. wstąpił do Towarzystwa Jezusowego. W latach 1959-1962 studiował na Wydziale Filozoficznym Uniwersytetu we Fryburgu, a w latach 1964-1968 na Wydziale Teologicznym Uniwersytetu w Innsbrucku, gdzie uzyskał tytuł magistra na podstawie pracy o możliwości zbawienia poza Kościołem według Karla Rahnera. W 1974 r. uzyskał stopień doktora teologii na Papieskim Uniwersytecie Gregoriańskim 
w Rzymie na podstawie krytycznego i systematycznego studium teologii trynitarnej Karla Rahnera. W tymże roku rozpoczął wykłady na Papieskim Uniwersytecie Katolickim w Rio de Janeiro. W latach 1975-1977 sprawował funkcję dziekana Wydziału Teologicznego. W 1979 r. wyjechał do Belo Horizonte jako profesor teologii systematycznej na Wydziale Teologicznym Towarzystwa Jezusowego w Brazylii. W tym czasie był zaangażowany w dialog między chrześcijaństwem a współczesną kulturą. W 1993 r. powrócił do Rio de Janeiro, gdzie prowadził zajęcia m.in. z teologii religii, inkulturacji wiary i sytuacji chrześcijaństwa w nowoczesnym społeczeństwie. W latach 2001-2003 ponownie pełnił funkcję dziekana tamtejszego Wydziału Teologicznego, a jednocześnie - jako visiting professor - prowadził wykłady z inkulturacji wiary na Uniwersytecie Gregoriańskim w Rzymie. W ostatnich latach opracowywał zagadnienia eklezjologiczne dla Krajowej Konferencji Biskupów w Brazylii. Był zapraszany w roli eksperta na zebrania Rady Biskupów Ameryki Łacińskiej (CELAM). Należał do Międzynarodowej Komisji Teologicznej w Watykanie, kiedy jej przewodniczącym był kard. Józef Ratzinger.

Autor 14 książek i 105 artykułów naukowych oraz współtwórca innych 31 tomów. Promotor 31 prac magisterskich i 14 doktorskich. Członek redakcji naukowej następujących czasopism: „Revista Teología” (Argentyna) „Actualidades Teológicas” (Chile), „Cuestiones Teológicas” (Kolumbia), „Stromata” (Argentyna), „Revista Eclesiástica Brasileira” (Brazylia), „Kairós” (Brazylia), „Revista de Cultura Teológica” (Brazylia).

Nabil E 1 - K h o u ry urodził się 5 kwietnia 1941 r. w Mtaile-Chouf w Libanie. Studia na Uniwersytecie św. Józefa w Bejrucie, uwieńczył dyplomem z filozofii (1965) i teologii (1967). W latach 1967-1973 na uniwersytetach w Tybindze i Regensburgu, gdzie profesorem był wówczas Józef Ratzinger, kontynuował studia z filozofii, teologii, nauk politycznych, studiów wschodnich i lingwistyki. Na pierwszym uzyskał stopień doktora na podstawie dysertacji dotyczącej historii duchowej w ujęciu św. Efrema Syryjczyka. Następnie opublikował rozprawę zatytułowaną Problèmes d'herméneutique: l'exemple du Liban na Sorbonie w Paryżu oraz współpracował w przygotowaniu dzieła zbiorowego Werke von Schelling, opracowanego przez Bawarską Akademię Nauk w Monachium. W latach 1974-1977 wykładał na Uniwersytecie Ludwika Maksymiliana w Monachium, a od 1977 r. na Uniwersytecie Libańskim w Bejrucie. Aktualnie na tejże uczelni oraz na Uniwersytecie w Tybindze jest profesorem Filozofii i Literatury Porównawczej. Jako visiting profesor prowadził wykłady na 
na wielu uniwersytetach w Niemczech (Eichstätt-Ingolstadt, Moguncja, Fryburg) oraz w Austrii (Salzburg).

Szczęśliwy mąż i ojciec dorosłej już trójki dzieci. Tłumacz na język arabski Opera omnia Józefa Ratzingera, a także dzieł Kanta, Hegla i Goethego. Autor wielu artykułów naukowych i uczestnik międzynarodowych konferencji. Współtwórca ważnych projektów wydawniczych: Beirut Contributions to Theology, Beirut Contributions to Philosophy, Masterpieces of German Literature in Arabic translation.

Uroczystość wręczenia Nagrody Ratzingera 2015 poprzedziły dwa ważne wydarzenia: otwarcie w Pontificium Collegium Teutonicum w Watykanie biblioteki poświęconej życiu i myśli papieża-emeryta oraz Międzynarodowe Sympozjum zorganizowane z okazji 10. rocznicy encykliki Deus caritas est w perspektywie Jubileuszu Miłosierdzia. Sama uroczystość była złożona z dwóch komplementarnych części. W Instytucie Patrystycznym Augustinianum odbyła się konferencja poświęcona prezentacji działalności Fundacji Józefa Ratzingera - Papieża Benedykta XVI oraz różnych centrów studiów jego myśli w wielu krajach, natomiast w Sala Regia Pałacu Apostolskiego odbyła się ceremonia wręczenia nagrody.

Kardynał Gerhard Ludwig M ü 11 e r, prefekt Kongregacji Nauki Wiary, w słowie wprowadzającym, wskazał na niezwykłą głębię i nieocenioną wartość teologiczną myśli Benedykta XVI. Wyjaśnił znaczenie Nagrody Ratzingera, a wraz z gratulacjami dla laureatów wyraził radość, że stanowi ona wyraźny znak powszechności Kościoła.

Gospodarz miejsca i rektor Instytutu Patrystycznego, o. prof. Robert D o d a r o OSA, po pozdrowieniu wszystkich zebranych, zaprezentował nową ofertę studiów podyplomowych: „Joseph Ratzinger. Studies and spirituality". Wyjaśnił, że kursy rozpoczną się w lutym 2016 r. i będą prowadzone w języku angielskim i włoskim.

Christian S c h a 11 e r, dyrektor Instytutu Papieża Benedykta XVI w Ratyzbonie i redaktor naczelny Opera omnia, zaprezentował postęp prac mających na celu wydanie znanych już dzieł oraz dotąd jeszcze niewydanych, mających niekiedy charakter manuskryptów.

Z kolei prał. Giuseppe A. S c o t t i, przewodniczący Fundacji Józefa Ratzingera - Papieża Benedykta XVI, wyjaśnił, w jaki sposób wpisuje się ona we współczesne wyzwania teologii katolickiej, powołanej do odczytywania 
i ukazywania sensu przyniesionego przez Chrystusa w kontekście nowych kultur i środowisk na wszystkich szerokościach geograficznych. Gratulując laureatom, podkreślił, że stanowią oni doskonały przykład takiego cierpliwego dialogu ze światem i służby wielu pokoleniom przez ukazywania słowa Bożego jako źródła fundamentalnych wartości.

Ksiądz dr Mariusz K u c i ń s k i, dyrektor Centrum Studiów Ratzingera, działającego we współpracy z Kujawsko-Pomorską Szkołą Wyższą w Bydgoszczy, przypomniał historię międzynarodowych konferencji, z których pierwsza odbyła się w 2011 r. w Bydgoszczy (uczestniczyli w niej przedstawiciele 32 uniwersytetów z całego świata) i przedstawił imponujące dokonania polskiego Centrum Studiów, osiągnięte zaledwie w ciągu czterech lat.

Justinus P e ch, OCist., przedstawiciel Philosophisch-Theologische Hochschule Benedikt XVI, Heiligenkreuz (Austria), w ciekawej prezentacji multimedialnej ukazał nie tylko piękną infrastrukturę uczelni, w tym nowoczesne aule i bibliotekę, ale także ośmioletnie dokonania Wydziału, który cieszy się coraz większą popularnością i liczbą studentów.

Największy aplauz uczestników konferencji popłynął jednak w kierunku Bolawalana (Sri Lanka) po obejrzeniu filmiku prezentującego powstanie i aktualny stan The Benedict XVI Cultural Institute (BCI). Uczelnia ta, poświęcona przez papieża Franciszka w styczniu 2015 r., stanowi ważne i nowoczesne centrum edukacji i promocji wartości humanistycznych i chrześcijańskich w tym azjatyckim kraju. Ksiądz prof. Stefan H e id, dyrektor Sekcji Ratzingera w bibliotece Pontificium Collegium Teutonicum, opowiedział o jej uroczystej inauguracji, która odbyła się 18 listopada 2015 r., oraz przedstawił zasady funkcjonowanie i plany rozwoju. Zaprosił wszystkich do korzystania z jej zbiorów, liczących już ponad tysiąc pozycji, oraz nadsyłania materiałów związanych z życiem, myślą i działalnością papieża-emeryta, który ze swej strony przekazał sekcji ok. 200 książek. Następnie zaprezentowany kolejny tom (6/2) serii Opera omnia Józefa Ratzingera-Benedykta XVI.

Kolejnym punktem konferencji był wykład o. prof. Nello C i p r i a n i OSA na temat chrystologii kard. Józefa Ratzingera/Benedykta XVI. Prelegent podkreślił nie tylko wnikliwość jego myśli i precyzję pojęciowo-semantyczną, ale także leżącą u ich podstaw osobowość wierzącego i pokornego, acz nieustępliwego badacza. Taka postawa prowadziła do przeciwstawienia się redukcjonistycznym interpretacjom postaci Jezusa Chrystusa, prawdziwego Boga-Człowieka i jedynego Zbawiciela świata. Prelegent wymienił trzy współczesne nurty kulturowe i kierunki teologii: 
historyczno-krytyczną, polityczną i pluralistyczną, które stały się przedmiotem polemiki podjętej przez papieża-emeryta. Pierwszemu, charakterystycznemu dla egzegezy protestanckiej pierwszej połowy XX w., zarzucił atomizację Biblii i odejście od hermeneutyki wiary w kluczu chrystologicznym. Jako zasadniczy błąd chrystologii politycznej, która znalazła swój szczególny wyraz w teologii wyzwolenia, wskazał sprowadzenie rzeczywistości eschatologicznej do wymiarów ziemskiej doczesności, wbrew słowom Jezusa, który mówił, że Jego królestwo nie jest z tego świata. Za największe współczesne zagrożenie, widoczne zwłaszcza w cywilizacji zachodniej, uznał teologię pluralistyczną, opartą na założeniu, że religie monoteistyczne i misyjne są źródłem nietolerancji. Nurt ten chce widzieć w Jezusie Chrystusie jedynie mistrza duchowości, na równi z innymi założycielami religii, oświeconego, ale nie Światłość świata, nauczyciela, ale nie odwieczny Logos. Zdaniem Benedykta XVI, najskuteczniejszym antidotum na takie poglądy jest prawda o zmartwychwstaniu, które ostatecznie objawia i potwierdza wyjątkową pozycję Jezusa.

Po krótkiej przerwie, uczestnicy uroczystości przybyli do Pałacu Apostolskiego. Centralna uroczystość wręczenia Nagrody Ratzingera odbyła się w przepięknej i bogato zdobionej freskami Sala Regia. Uroczystościom przewodniczył kard. Gerhard Ludwig M ü 11 e r, prefekt Kongregacji Nauki Wiary. Przy stole prezydialnym zasiedli ponadto abp Luis Francisco L a d a r i a, sekretarz tejże Kongregacji oraz Komitetu Naukowego Watykańskiej Fundacji Józefa Ratzingera - Benedykta XVI oraz prał. Giuseppe S c o t t i, przewodniczący Fundacji. Pośród wielu dostojników obecni byli kardynałowie: Tarcisio B e r t o n e, Paul Josef C o r d e s, Prosper G r e c h, Kurt Koch, Manuel Monteiro d e Castro i Leonardo Sandri, arcybiskupi Giovanni Angelo B e c c i u i Edmond F a r h a t, inni przedstawiciele Kościoła rzymskokatolickiego i maronickiego, laureaci poprzednich edycji nagrody (ks. prof. Waldemar Chrostows ki i prof. Christian $\mathrm{S} \mathrm{c} \mathrm{h} \mathrm{a} \mathrm{ll} \mathrm{e} \mathrm{r),} \mathrm{członkowie} \mathrm{organizacji} \mathrm{związanych} \mathrm{z} \mathrm{promocją} \mathrm{myśli} \mathrm{Józefa}$ Ratzingera i liczni goście.

Ceremonię rozpoczął abp Luis $\mathrm{L}$ a d a r i a, prezentując sylwetki naukowe obydwu laureatów. Wskazał nie tylko na ich ogromny dorobek naukowy i dydaktyczny, ale także na zdolność poszukiwania nowych dróg teologicznego myślenia w dialogu ze swoimi środowiskami i zmieniającą się sytuacją kulturową świata.

Z kolei prał. Giuseppe $\mathrm{S}$ c o t t i w yjaśnił, dlaczego papież Franciszek, który decyduje o przyznaniu nagrody, chciał w tym roku uhonorować 
właśnie tych badaczy i wykładowców. Wskazał na fakt, że obaj pochodzą z terenów, określanych jako „peryferie świata”, gdzie doświadcza się, często w dramatyczny sposób, powstawania i rozwoju zupełnie nieznanych dotąd kultur, zalewających miasta i nowe ogromne obszary. „Te nowe kultury - jak napisał papież w encyklice Evangelii gaudium (nr 73) - rodzą się nadal w ogromnych skupiskach ludzkich, gdzie chrześcijanin nie jest już promotorem lub twórcą sensu, natomiast otrzymuje od nich inne języki, symbole, przesłania i paradygmaty, dające nowe ukierunkowania życia, często sprzeczne z Ewangelią Jezusa". Ksiądz Scotti, przypominając dalej słowa Ojca Świętego, podkreślił, że w wielu miejscach na świecie „doszło do duchowego «pustynnienia», będącego owocem projektu społeczeństw, które pragną budować się bez Boga albo które niszczą swoje chrześcijańskie korzenie" (EG nr 86). Wskazał następnie na laureatów, pochodzących z Brazylii i Bliskiego Wschodu, jako przykłady przenikliwych teologów, którzy wcześniej od innych potrafili rozpoznać i opisać przemiany, określane mianem wielokulturowości, i którzy przez cierpliwą pracę dydaktyczną i piśmienniczą ukazali, jak bardzo konieczna jest dzisiaj „ewangelizacja, która rzuciłaby światło na nowe sposoby nawiązywania relacji z Bogiem, z innymi ludźmi i ze środowiskiem, a która odbudowałaby fundamentalne wartości” (EG nr 74). Na koniec wyraził nadzieję, że wybór o. prof. Mario de França Miranda i prof. Nabil El-Khoury jako laureatów Nagrody Ratzingera może być znakiem nadziei dla wielu wierzących, żyjących na „peryferiach świata”.

Po tych przemówieniach głos zabrał kard. Gerhard M ü 11 e r, delegowany przez papieża Franciszka do wręczenia nagrody. Podkreślił, że Nagroda Ratzingera, przyznawana dotychczas teologom europejskim, w piątej edycji popłynie dalej na wschód i zachód. Powszechność Kościoła oparta na jedności wiary znajduje dziś wyraz w różnorakich formach wyrazu, wyrosłych na bazie odmiennych kultur. Katolickość jest zatem niezmiennym darem Boga, a jednocześnie dynamicznym pryncypium, które pozwala Chrystusowi przyjmować właściwe, choć wciąż nowe formy w Ciele Kościoła na całym świecie. Tegoroczni laureaci są znakiem powszechności Kościoła nie tylko w sensie geograficznym, ale również czasowym, jako że Bliski Wschód jest kolebką chrześcijaństwa, a „nowy świat” poznał Ewangelię dopiero w czasach nowożytnych. Na koniec kard. Müller złożył im gratulacje i wyrazy serdecznego uznania w następujących słowach: „Drodzy Profesorowie: Nabil el-Khoury i Mario De França Miranda! Jestem szczęśliwy, że w imieniu papieża Franciszka, mogę wręczyć wam 
Nagrodę Ratzingera 2015, w uznaniu waszych wybitnych zasług na polu studiów i wielorakiej działalności akademickiej i formacyjnej. Składam wam gratulacje w imieniu osobistym, jak również wszystkich tych, którzy z radością przybyli, by was uhonorować i wyrazić uznanie dla waszych dokonań. Z serca dziękuję i składam najserdeczniejsze życzenia!" Nastąpił podniosły moment wręczenia nagród i dyplomów obydwu laureatom. Sala Regia w Pałacu Apostolskim wypełniła się gromkimi oklaskami.

Kiedy wydawało się, że uroczystość dobiega końca, miały miejsce dwie niespodzianki. Kardynał Gerhard Müller ponownie zabrał głos, by obwieścić przyznanie specjalnych medali dla laureatów Nagrody Ratzingera z poprzednich lat, w uznaniu ich zasług jako ambasadorów dialogu wiary i nauki oraz Kościoła i kultur. Z jego rąk odznaczenie przyjęli obecni na sali ks. prof. Waldemar Chrostowski i prof. Christian S challer. Drugą niespodzianką było krótkie przemówienia o. M i r a n d y, który opanowując wzruszenie - podziękował za przyznanie zaszczytnej nagrody i wyraził radość z powodu dołączenia do zacnego grona laureatów. Uznał, że zapewne wielu zasłużyło na nią bardziej, i powiedział, że przyjmuje ją jako wyraz uznania dla teologii katolickiej poszukującej dialogu z innymi religiami i kulturami. Prof. Nabil E 1 - K h o u r y z apowiedział, że swoje podziękowanie i refleksje wyrazi podczas wieczornego okolicznościowego bankietu. Na tym zakończyła się oficjalna część uroczystości, lecz indywidualne gratulacje trwały jeszcze długo, czemu sprzyjała historyczna i przepięknie ozdobiona freskami Sala Regia w Pałacu Apostolskim na Watykanie. 